\title{
PENGARUH LABEL HALAL DAN HARGA TERHADAP KEPUTUSAN MEMBELI PRODUK KOSMETIK WARDAH (Studi Pada Mahasiswi Prodi Manajemen Universitas Bengkulu)
}

\author{
Oleh
}

\author{
FENTI MAYANG SARI, ANDY MAKHRIAN, KHAIRIL BULDANI \\ Program Studi Ilmu Komunikasi Fakultas Ilmu Sosial dan Politik \\ Universitas Bengkulu
}

\begin{abstract}
This study aims to find out how the influence between halal and price labels influences consumers in making buying decisions, to know more about identifying products, buying and using products. This study uses a closed questionnaire in data collection and literature studies and other references related to research problems. The sample in this study was a student of UNIB management which was taken using a purposive sampling method with the criteria of using wardah cosmetic products for approximately 4 months from this study and having knowledge of beauty care, then analyzing the data using statistical tests of multiple linear regression analysis ( $F$ test and $T$ test). Based on the results of the research, it can be seen halal and price labels. So it can be concluded that the results of halal and price labels partially ( $\mathrm{T}$ Test) null hypothesis (HO) are accepted which means there is no positive influence, but overall both of these variables influence consumers' decision to buy and choose wardah products.
\end{abstract}

Keywords: halal labels, prices, buying decisions

\section{PENDAHULUAN}

Dewasa ini kebutuhan wanita akan produk kosmetik dan perawatan kulit semakin meningkat. Tidak jarang, kosmetik menjadi kebutuhan primer dalam belanja bulanan setiap wanita. Wanita cenderung membelanjakan uangnya lebih banyak untuk penampilan seperti pakaian, kosmetik, alat-alat perawatan kecantikan rambut dan sebagainya (Kasali,1992:34). Indonesia merupakan pasar komunitas muslim yang cukup besar, selain karena sebagian besar penduduk Indonesia merupakan kaum muslim, begitu juga dengan penduduk muslim di Bengkulu yang berjumlah lebih dari 1,669,081 jiwa, agama kristen sebanyak 28, 724 jiwa, dan agama katolik sebanyak 6,364 jiwa (Sp2010.bps.go.id) Pemahaman yang semakin baik terhadap agama membuat konsumen muslim menjadi makin selektif dalam memilih produk halal yang akan dikonsumsi, baik itu produk makanan, obat-obatan, minuman bahkan produk kosmetik. Halal diperuntukkan bagi segala sesuatu yang baik dan bersih yang dimakan atau dikonsumsi oleh manusia menurut sayri'at islam.

Sejalan dengan ajaran Islam, umat muslim menghendaki agar produk-produk yang akan dikonsumsi tersebut dijamin kehalalan dan kesucianya. Menurut ajaran Islam mengkonsumsi yang halal, suci dan baik merupakan perintah agama dan hukumnya wajib (Departemen Agama, 2003).

Kosmetik dan obat-obatan keduanya disebut halal apabila bahan-bahan yang terkandung dalam bahan baku pilihan yang sesuai dengan syari'at islam dan memiliki 
sertifikat halal dari MUI. Indonesia merupakan negara yang mayoritas muslim, maka jaminan kehalalan pada kosmetik sangat penting, karena kosmetik yang beredar dipasaran nyatanya masih banyak yang belum mencantumkan label halal pada kemasan produknya, halal diperuntukan bagisegala segala sesuatu yang bersifat baik dan bersih bagi manusia, sebagaimana Allah telah menegaskan dalam QS. Al-Maidah ayat 3.

Ayat ini menjelaskan bahwa "memakan" bukan hanya di artikan sebagai memakan lewat mulut, tapi memakan tersebut diartikan sebagai mengonsumsi dalam artian menggunakan olahan babi untuk berbagai keperluan termasuk kosmetik. Halal atau tidak merupakan suatu keamanan yang sangat mendasar bagi umat Islam.

Konsumen muslim cenderung memilih produk yang telah dinyatakan halal dibandingkan dengan produk yang belum dinyatakan oleh lembaga berwenang.

Selain itu pada Al-Quran surat AlNahl ayat 114 juga dijelaskan Allah memerintahkan kepada manusia untuk memakan (mengkonsumsi) makanan yang halal, hal ini dapat dianalogikan pada produk selain makanan yang dikonsumsi konsumen muslim termasuk kosmetik dan perawatan kulit.

Kesadaran akan mengkonsumsi produk halal pada konsumen muslim, merupakan akibat dari pemahaman agama yang baik. Hal ini akan berdampak semakin tingginya konsumen yang perduli tentang sertifikat label halal pada produk yang dibelinya, karena saat ini banyak konsumen yang semakin kritis dan memiliki pengetahuan produk yang baik sebelum melakukan keputusan pembelian.

Kosmetik yang tidak halal berarti dalam proses pembuatannya serta bahan yang digunakan menggunakan zat-zat yang diharamkan secara islam (Sumarwan, 2011:209).

Sedangkan label halal adalah perizinan pemasangan kata "Halal" pada kemasan produk dari suatu perusahaan oleh Badan POM. Izin pencantuman "Label Halal" pada kemasan produk dikeluarkan oleh lembaga khusus yaitu LPPOM MUI (Lembaga Pengkajian Pangan Obat-Obatan dan Kosmetika

Majelis Ulama Indonesia. Lembaga tersebut adalah lembaga yang bertugas untuk meneliti, mengkaji, menganalisa dan memutuskan apakah produk-produk baik pangan dan turunannya, obat-obatan dan kosmetika sudah aman untuk dikonsumsi baik dilihat dari sisi kesehatan maupun dari sisi agama Islam yakni telah dinyatakan halal atau boleh dan baik untuk dikonsumsi bagi umat Muslim, berikut label halal resmi dari MUI (www.halalmui.org).

Selain label halal, persoalan konsumen dalam memilih produk adalah harga. Harga juga merupakan salah satu faktor konsumen untuk menentukan keputusan pembelian pada produk. Dimana harga adalah sejumlah uang yang dibebankan atas suatu produk atau jasa, atau jumlah dari nilai yang ditukar konsumen atas manfaat-manfaat karena memiliki atau menggunakan produk atau jasa tersebut (Kotler \& Amstrong, 2001).

Pengaruh harga terhadap keputusan pembelian sangatlah penting, karena dengan tingkat harga yang dinilai terlalu tinggi akan menjadikan pertimbangan pembelian bagi konsumen, dimana mayoritas masyarakat Indonesia memiliki ekonomi menengah kebawah.

Sementara itu masih banyak produk yang beredar dipasaran belum mencantumkan label halal resmi dari LPPOM-MUI pada kemasannya.

Artinya masih banyak produk yang beredar dimasyarakat belum memiliki sertifikat halal.Kosmetik tidak halal berarti dalam proses pembuatannya menggunakan zat-zat yang diharamkan secara islam, dan akan menciptakan keraguan serta perasaan yang tidak tenang. Selain keraguan yang timbul akibat kesalahan pemilian kosmetik masalah kesehatan juga menjadi ancaman bagi konsumen. 
Masalah-masalah yang timbul akibat efek samping dari kesalahan pemilihan kosmetik membuat konsumen melakukan pertimbangan sebelum membeli.Banyak kosmetik yang mengandung bahan kimia berbahaya diantaranya sintetis dan berbahan dasar minyak bumi yang dapat memicu masalah kesehatan seperti iritasi kulit, hingga kanker (health.detik.com).

Banyak kasus yang terjadi disebabkan oleh kandungan zat berbahaya dalam kosmetik. Di Yogyakarta, terjadi banyak kasus efek samping seperti penyakit kulit diakibatkan penggunaan hidrokinon berlebihan pada kosmetik, 40 kasus terjadi karena kandungan hidrokinon lebih dari $2 \%$.

Kasus paling banyak adalah penggunaan produk pemutuh yang tidak berlabel halal dari LPPOM MUI dengan harga yang terjangakau karena keinginan untuk mencerahkan kulit wajah namun yang terjadi kesalahan penggunaan kosmetik yang mengakibatkan iritasi, kulit menghitam bahkan alergi (health.detik.com).

Kasus diatas adalah fakta bahwa kebutuhan untuk tampil cantik menyebabkan wanita melakukan berbagai cara yang akhirnya merugikan diri sendiri.

Konsumen wanita harus lebih teliti dalam memilih kosmetik selain alasan kesehatan, keterangan halal dan harga produk sangat berdampak terhadap keputusan pembelian.

Sebagai produk kosmetik, pada kemasannya produk wardah telah mempunyai label halal dari lembaga yang berwenang.

Disisi lain Wardah juga mempunyai harga yang cukup terjangkau sesuai dengan kualitasnya. Hal ini menjadikan wardah sebagai objek penelitian bagi penulis apakah label halal dan harga pada produk kosmetik wardah menjadi hal yang memang dipertimbangkan oleh konsumen.

Dalam keputusan pembelian, mahasiswi juga ikut serta karena mahasiswi merupakan salah satu konsumen kosmetik, dalam kesehariannya mahasiswipasti menggunakan kosmetik, maupun produk perawatan kulit. agar dapat menunjang penampilannya seharihari.

Produk kosmetik Wardah merupakan jawaban bagi konsumen muslim karena Wardah merupakan kosmetik yang mengusung tema "kosmetik halal" produk ini jelas mencantumkan label halal pada produk yang dipasarkan.

Dalam mendukung wanita untuk tampil cantik sesuai karakternya masing-masing, yang memiliki tiga konsep kecantikan :

1. Pure and Safe

Produk Wardah mengandung bahanbahan baku pilihan, aman dan halal.

2. Beauty expert

Citra awal Wardah sebagai kosmetik yang ditujukan untuk wanita muslim telah berkembang pesat menjadi produk yang dapat dinikmati kalangan lebih luas

3. Inspiring beauty

Sejak tahun 1995 hingga saat ini, Wardah selalu meyakini kecantikan yang menginspirasi. Wanita Indonesia telah mengadopsi dinamika kemajuan dunia, namun ia tak pernah meninggalkan nilai budaya timur yang santun. Bagi wanita Wardah, kosmetik tidak hanya untuk tubuh akan tetapi juga untuk jiwa.

Dari penjelasan diatas maka, penelitian ini dilakukan untuk memperoleh informasi yang lebih jelas serta disertai bukti ilmiah mengenai bagaimana pengaruh label halal dan harga terhadap keputusan pembelian, perlu dilakukan suatu penelitian ilmiah.

\section{METODE PENELITIAN}

Ditinjau dari data yang digunakan penelitian ini menggunakan metode penelitian kuantitatif, metode penelitian kuantitatif diartikan sebagai metode penelitian berlandaskan pada filsafat positivisme yang digunakan untuk meneliti populasi atau sampel tertentu pengumpulan data menggunakan instrument penelitian, analisis data bersifat kuantitatif/statistik dengan tujuan menguji 
hipotesis yang telah ditetapkan (Sugiyono, 2012:11).

Penelitian kuantitatif menyajikan data dalam bentuk deskripsi dengan menggunakan informasi berupa angkaangka statistik. Riset kuantitatif menggambarkan atau menjelaskan suatu masalah yang hasilnya dapat digeneralisasikan. Metode yang digunakan adalah metode survei, survei adalah metode riset dengan menggunakan kuisioner sebagai instrumen pengambilan datanya (Kriyantono, 2008:57).

Berdasarkan pemahaman tersebut, peneliti ingin menjelaskan dan menggambarkan apakah terdapat pengaruh label halal dan harga pada produk kosmetik wardah terhadap keputusan membeli (studi mahasiswi manajemen angkatan 2017 universitas bengkulu) melalui sumber data primer berupa kuisioner yang akan disebarkan peneliti koresponden yaitu mahasiswi manajemen angkatan 2017yang merupakan konsumen produk wardah yang dapat memenuhi kriteria atau karakteristik yang telah peneliti buat sebelumnya.

\section{Variabel Penelitian}

Variabel penelitian adalah segala sesuatu yang berbentuk apa saja yang ditetapkan oleh peneliti untuk dipelajari sehingga diperoleh informasi tentang hal tersebut, kemudian ditarik kesimpulannya (Sugiyono, 2012:38). Dalam penelitian ini terdapat dua varibel sebagai berikut:

1. Variabel Independen

Variabel Independen merupakan variabel bebas atau variabel yang memengaruhi variabel lain. Variabel bebas adalah variabel yang menjadi sebab terjadinya atau terpengaruhnya variabel terikat dimana faktornya diukur, dimanipulasi atau dipilih oleh peneliti untuk menentukan hubungan dengan suatu gejala yang diobservasi. Dalam penelitian ini terdapat dua variabel independen yaitu label halal (X1), dan harga (X2).
2. Variabel Dependen

Variabel dependen adalah variabel terikat. Variabel ini merupakan variabel yang dipengaruhi atau yang menjadi akibat karena adanya variabel bebas. Pada penelitian ini variabel dependennya adalah keputusan membeli konsumen (Y).

\section{Teknik Pengumpulan Data}

1. Kuisioner

Data dalam penelitian ini diperoleh langsung dari penyebaran kuisioner, peneliti membagi satu-persatu kuisioner kepada responden yang merupakan mahasiswi Manajemen UNIB 2017 pengguna kosmetik wardah. Responden memberikan jawaban pada kuisioner dengan cara memilih salah satu jawaban apakah SS, S, KS, TS, STS.

2. Studi Kepustakaan

suatu metode pengumpulan data dengan cara mempelajari literaturliteratur dari buku-buku, referensi dari jurnal penelitian yang relevan dengan penelitian yang dilakukan.

3. Wawancara

\section{Teknik Analisa Data}

Teknik yang digunakan dalam menganalisis data penelitian ini adalah metode kuantitatif uji statistic regresi berganda dengan rumus:

$$
\mathbf{Y}=\mathbf{a}+\mathbf{b}_{1} \mathbf{X}_{1}+\mathbf{b}_{2} \mathbf{X}_{2}
$$

Kemudian untuk mengetahui ada tidaknya pengaruh atau kontribusi keseluruhan antara variabel-variabel yang dapat diuji Ftest pada taraf signifikansi 5\% (yang berarti kemungkinan terjadi kesalahan dalam penelitian ini adalah sebesar 5\% sehingga tingkat kepercayaan pada penelitian ini adalah sebesar 95\%).

Selanjutnya untuk mengetahui besar pengaruh antara kedua variabel dilakukan koefisien determinasi :

$\mathbf{K P}=\mathbf{R}_{2} \times 100 \%$ 


\section{HASIL DAN PEMBAHASAN}

Hasil penelitian ini membahas tentang pengaruh label halal dan harga terhadap keputusan membeli produk kosmetik wardah. Sampel pada penelitian ini berjumlah sebanyak 30 orang yang merupakan mahasiswi manajemen UNIB konsumen kosmetik wardah. Dari hasil pengujian hipotesis terbukti bahwa variabel label halal dan harga secara parsial (menguji pengaruh variabel bebas secara terpisah terhadap variabel terikat) maupun secara simultan (menguji pengaruh variabel bebas secara bersamasama terhadap variabel terikatnya) tidak berpengaruh terhadap keputusan membeli produk kosmetik wardah.

Dan dari hasil analisis regresi, diketahui bahwa pengaruh label halal dan harga sebesar 17,905\%. Sisanya 82,095\% dipengaruhi oleh variabel lain yang tidak diteliti di dalam penelitian ini. Hal ini menunjukkan bahwa label halal memiliki pengaruh terhadap keputusan membeli meskipun pengaruhnya tidak terlalu kuat antara variabel $\mathrm{X} 1$ ke $\mathrm{Y}$ dan $\mathrm{X} 2$ ke $\mathrm{Y}$, namun tetap disimpulkan bahwa variabel label halal dan harga berpengaruh secara keseluruhan terhadap keputusan membeli produk kosmetik wardah.

Berdasarkan kerangka pemikiran dalam penelitian ini, pengaruh yang dihasilkan dari label halal dan harga diharapkan dapat membuat konsumen terpengaruh untuk melakukan keputusan membeli, namun tidak teruji dalam penelitian ini.

Artinya kedua variabel tersebut tidak memiliki pengaruh yang besar, sehingga responden atau reaksi yang dihasilkan adalah negative.

Tidak terdapatnya pengaruh label halal atau reaksi yang dihasilkan bersifat negatif ini dapat dibuktikan melalui hasil tanggapan responden pada item pernyataan keempat yang bernilai negatif pada variabel $\mathrm{X} 1$ yang mana sebagian responden menjawab label halal tidak menjadi pertimbangan dalam memilih produk kosmetik wardah sebelum melakukan pembelian, sehingga dihasilkan angka 95 berdasarkan tabel data tabulasi label halal (X1).

Selanjutnya yang menyebabkan respon yang dihasilkan bersifat negatif dapat dilihat dari jawaban responden pada item pernyataan kelima varibael X2 yang mana sebagian besar responden menjawab pebedaan harga di pasar tradisonal dan pasar modern atau minimarket menjadi pertimbangan dalam membeli kosmetik wardah, sehingga dihasilkan angka 81 berdasarkan tabel data tabulasi harga X2.

\section{PENUTUP}

Penelitian yang berjudul pengaruh label halal dan harga terhadap keputusan membeli produk kosmetik wardah bertujuan untuk mengetahui adakah pengaruh label halal (Variabel X1) dan harga (Variabel X2) terhadap keputusan membeli produk kosmetik wardah. Berdasarkan hasil penelitian dan pembahasan dapat diambil kesimpulan sebagai berikut :

1. Adanya label halal dan harga berpengaruh secara simultan terhadap keputusan membeli produk kosmetik wardah, hal ini dapat dilihat dari Fhitung lebih besar dari Ftabel (Fhitung $=22,94436>$ Ftabel $=3,35$ ), jadi dapat diartikan bahwa secara simultan X1 (label halal) dan X2 (harga) berpengaruh terhadap keputusan membeli produk kosmetik wardah (Y).

2. Adanya variabel label halal berpengaruh tidak terlalu signifikan terhadap keputusan membeli produk kosmetik wardah, hal ini dapat dilihat dari nilai thitung variabel X1sebesar 0,03092 lebih kecil dari ttabelsebesar 2,04841.

3. Adanya variabel harga berpengaruh tidak terlalusignifikan terhadap keputusan membeli, hal ini dapat dilihat dari nilai thitung variabel X2 sebesar -0,06379 lebih kecil dari ttabel sebesar 2,04841. 
4. Berdasarkan hasil penelitian yang telah dilakukan, dapat disimpulkan bahwa pengaruh label halal dan harga terhadap keputusan membeli produk kosmetik wardah terdapat pengaruh yang kecil yakni sebesar $17,905 \%$. Sisanya 82,095\% dipengaruhi oleh variabel lain yang tidak diteliti di dalam penelitian ini.

\section{Saran}

Berdasarkan hasil penelitian yang dilakukan maka peneliti memberikan beberapa saran sebagai berikut:

1. Perusahaan sebaiknya tetap mencantumkan label halal beserta harga pada semua produknya dan menambah pencantuman label halal bagi produk yang belum mendapat label halal.

2. Sambutan hangat dari konsumen menandai bahwa produk wardah diterima dengan baik di Bengkulu terutama dikalangan mahasiswi. Oleh karenanya perusahaan harus tetap bertanggung jawab akan kualitas dan mutu produk untuk menjaga loyalitas konsumen.

3. Perusahaan harus bekerja sama dengan LPPOM MUI dan pakarpakar kesehatan untuk mendidik masyarakat tentang pentingnya kosmetik yang tidak mengandung bahan berbahaya atau zat-zat yang dilarang dalam syariat islam dan suci. Pendidikan tersebut sebaiknya dilakukan di wilayah dengantingkat pengetahaun dan kesadaran akan kesehatan yang masih rendah.

\section{DAFTAR PUSTAKA}

Al-Quran dan Terjemahannya. 2008. Departemen Agama RI. Bandung: Diponegoro.

Al-Quran surat Al-Maidah ayat-3.

Al-Quran surat Al-Nahl ayat-114.

Apriyantono, Anton dan Nurbowo. 2003. Panduan Belanja dan Konsumsi Halal. Jakarta: Khairul Bayaan.

Bagian Proyek Sarana Dan Prasarana Produk Halal Direktorat Jenderal Bimbingan Masyarakat Islam Penyelenggaraan Haji, Himpunan Fatwa

Majelis Ulama Indonensia, Jakarta: Departemen Agama. 2003. hlm 287288.

Burhanuddin .2011. Pemikiran Hukum Perlindungan Konsumen dan Sertifikat Halal, (p.140,p.142), Universitas Islam Negeri Maulana Malik Ibrahim Maliki Press. Malang.

Cangara, Hafied. 2013. Perencanaan dan Strategi Komunikasi. Jakarta: PT Rajagrafindo Persada.

Kasali, Rhenald. 1992. Manajemen Periklanan Konsep dan Aplikasinya di Indonesia. Jakarta:PT Pustaka Utama Grafiti.

Kotler \& Keller. Manajemen Pemasaran Edisi 12 jilid 1. PT Indeks.

Kriyanto, Rachmat. 2008. Teknik Praktik Riset Komunikasi. Jakarta: Kencana.

Mowen, J.C dan Michael Minor. 2002. Perilaku Konsumen. Alih Bahasa: Lina Salim. Jilid I.Erlangga. Jakarta.

Philip Kotler dan Gerry Amstrong. 2001. Prinsip-Prinsip Pemasaran, Penerbit Erlangga: Jakarta. 